\title{
CHART OF PEER FEEDBACK TO RAISE WRITING AWARENESS IN EFL TEACHING
}

\author{
Dyah Kusumastuti \\ English Department \\ Universitas Muhammadiyah Purwokerto, Purwokerto, Indonesia \\ dyahkusumastuti@ump.ac.id
}

\begin{abstract}
This article reports on the results of a study concerning the type of mistakes produced by college students in analyzing their friends writing. The peer feedback was done through a chart. This study underlines the competence of students in analyzing the mistakes done by their friends. However, writing is a productive skill in language learning. Otherwise, learning foreign language in Indonesia also asks learners to master writing. The challenge in English writing is that it is not commonly done every single thing in life; it is done only in certain condition. Moreover, some mistakes are found in every topic they have written. The learners should be aware of grammar, diction, spelling, and many other kinds of mistakes in English writing. Instead, some data were found from the students' analysis. The results reveal that some students have done the feedback correctly, but some have not done it well.
\end{abstract}

Keywords: writing skill; mistakes; peer feedback

\section{INTRODUCTION}

Writing is a productive skill as it is actively done by learners including the EFL (English as a Foreign Language) learners. Therefore teachers' effort to make a comfortable learning atmosphere is a must. Teachers must know where their class will end up. Moreover, they are able to use a certain approach to make the students can engage well with English writing activity.

Report writing is an important part in a university education especially in English Education department. Therefore, it covers many goals such as critical thinking and self awareness. Critical thinking is needed as the students have seen some phenomenon around them. While self awareness is shown up when they are correcting and checking their friends. Using peer feedback can have many advantages in report writing. Likewise having this kind of feedback will engage the collaborative learning. It is achieved well in which it allows the students to interact, share and collaborate on what they have seen as mistake. Also peer feedback promotes autonomous learning which asks students to explore knowledge and learn independently. This study seeks to examine the utility of peer feedback as a support for the Indonesian university students to learn and engage in English report writing. Beside this study also underlines the competence of college students in doing peer feedback by using chart. The chart is completed with marks. The students must give a check to the types of mistakes they consider happen in their friends writing.
Moreover, it is done collaboratively to develop their selfrevision skill.

\section{ENGLISH WRITING AS A SKILL}

Writing is a progressive activity. This means that when someone first writes something down, she has already been thinking about what she is going to say and how she is going to say it. Then after she has finished writing, she reads over what she has written and makes changes and corrections. Besides, teacher as a facilitator must have an approach to teach writing basics to the students who have just entered the university. First, teacher can use process approach. In the process approach (Hayes, 1996; Hayes \& Flower, 1980 in Wakabayashi, 2008), the writing process is schematized by a recursive model of three main phases: planning, translating (writing), and reviewing. In the reviewing phase, writers look back on what they wrote and check for linguistic errors or problems that cause communication breakdown (e.g., poor logical connection). The advantage of this approach is the students become self-critical and objective writers who able to reflect on their writing.

Otherwise, a writer must know of the parts of essay she will write.

Parts of Essay:

- Introductory Paragraph

This part is written as an opening paragraph. The writer must tell the reader about general things.

- Body Paragraphs 
These parts are about the supporting paragraphs from the previous paragraph. In addition, there will be examples, percentages if needed, and more supporting data.

- Concluding Paragraph

This paragraph is to conclude all the discussion has been delivered in the previous paragraphs.

\section{FEEDBACK ON REPORT WRITING}

Both teachers and students are the two major feedback sources. Teacher feedback is usually given in a written form, but for more effective teacher feedback, Wakabayashi (2008) states that teacher-student conferencing has been proposed as an alternative method. Zamel in Wakabayashi (2008) says that the advantage of having this conferencing was that learners could respond to teacher comments on site in order to have solutions for problems. However, the large size of university classes is becoming the obstacle of teacher-student conferencing; therefore peer feedback is thought as another possibility of having interactive feedback.

In peer feedback, learners have chance to work collaboratively to exchange ideas and provide feedback on one another's writing for revisions. Learning and students motivation can be developed by having peer feedback (Hyland and Hyland, 2006), and it assists students understand the advantages and disadvantages of their writing, identify writing problems, and improve their writing competencies consequently (Cai, 2011). Peer feedback can also give a chance for the students to evaluate their own work critically (Cheng and Warren, 1996; Topping et. Al., 2000). Moreover, Wakabayashi (2008) concludes the advantages of peer feedback:

Learners receive more feedback than from the teacher alone

1. Learners receive comments from the learners' perspectives

2. Learners gain audience awareness

3. Learners focus on ideas for better revision

4. Learners can develop an understanding of good writing

5. Learners can improve their self-revision skills

6. Learners can enhance critical reading and critical thinking skills
7. Learners build a sense of community in the classroom

Nevertheless, there are also some things that make peer feedback is not suspenseful. Insufficient English proficiency and learner reluctant become the reasons why peer feedback is not really favorable to do.

\section{Participants}

\section{METHODOLOGY}

The participants in this study were 20 students of the second semester of university students from English Education Department in the academic year 2016/2017. All participants were officially involved in Report Writing class, where the teacher was also the researcher.

\section{Peer Feedback Sheet}

The students were given the peer feedback sheet. After writing a topic, they should give feedback by filling the sheet related to the mistakes they have considered from their friends writing. The form of the sheet can be seen as follows

\begin{tabular}{|c|l|l|l|l|l|l|l|}
\hline \multirow{2}{*}{ No } & \multirow{2}{*}{ Mistakes } & \multicolumn{4}{|c|}{ Kinds of mistakes } & \multirow{2}{*}{ Revisions } \\
\cline { 3 - 7 } & & Grammar & Spelling & Diction & Letter & Other & \\
\hline 1. & & & & & & & \\
\hline
\end{tabular}

\section{Procedure}

The data were collected during the learning process of Report Writing that took place in April-June. The data collection procedure had gone through some steps. First, the researcher provided a lecture in which she explained about the topic the students should report, beside she also explained the way the students can do peer feedback by the use of the peer response sheet. The learners then worked on a writing report activity for 45 minutes. Second, the students were then asked to have peer feedback for another $45^{\prime}$ by giving a mark $(\sqrt{ })$ in the kinds of mistakes found.

\section{RESULT AND DISCUSSION}

In the result, there are some data that are shown and will be discussed. The aspects of writing like grammar, spelling, diction, and letter become the tool to conclude the mistakes done by the first writer. Therefore, the second person should be the person who revised the mistake. 
a. Grammar

\begin{tabular}{|c|c|c|c|c|c|c|c|}
\hline \multirow{2}{*}{ No } & \multirow{2}{*}{ Mistakes } & \multicolumn{5}{|c|}{ Kinds of Mistakes } & \multirow{2}{*}{ Revisions } \\
\hline & & Grammar & Spelling & Diction & Letter & Other & \\
\hline 1. & $\begin{array}{l}\text { Proverty can be } \\
\text { definend }\end{array}$ & $\sqrt{ }$ & $\sqrt{ }$ & & & & Proverty can be definen \\
\hline 2. & $\begin{array}{l}\text { Governments of } \\
\text { developing countries } \\
\text { often cannot afford to } \\
\text { provide .... }\end{array}$ & $\sqrt{ }$ & & & & & $\begin{array}{l}\text { Governments of developing } \\
\text { countries are often cannot } \\
\text { afford to provide.... }\end{array}$ \\
\hline 3. & $\begin{array}{l}\text { For the rich people } \\
\text { should contribute } \ldots . .\end{array}$ & $\sqrt{ }$ & & & & & $\begin{array}{l}\text { For the rich people should } \\
\text { contributed .... }\end{array}$ \\
\hline 4. & $\begin{array}{l}\text { Love can cause a } \\
\text { positive effect. }\end{array}$ & $\sqrt{ }$ & & & & & $\begin{array}{l}\text { Love can caused a positive } \\
\text { effect. }\end{array}$ \\
\hline 5. & $\begin{array}{l}\text { You ordered to get } \\
\text { in... }\end{array}$ & $\sqrt{ }$ & & & & & You should to get in.... \\
\hline 6. & $\begin{array}{l}\text {...still much another } \\
\text { causing... }\end{array}$ & $\sqrt{ }$ & & & & & $\begin{array}{l}\text {... another factors } \\
\text { causing... }\end{array}$ \\
\hline 7. & $\begin{array}{l}\text { Almost all of the } \\
\text { traffic accident } \\
\text { preceded by } \\
\text { infraction rules of } \\
\text { traffic. }\end{array}$ & $\sqrt{ }$ & & & & & $\begin{array}{l}\text { Almost all of the traffic } \\
\text { accident was preceded by } \\
\text { infraction rules of traffic. }\end{array}$ \\
\hline 8. & $\begin{array}{l}\text { You still let yourself } \\
\text { to drive }\end{array}$ & $\sqrt{ }$ & & & & & $\begin{array}{l}\text { You are still let yourself to } \\
\text { drive }\end{array}$ \\
\hline
\end{tabular}

b. Spelling

\begin{tabular}{|c|c|c|c|c|c|c|c|}
\hline \multirow{2}{*}{ No } & \multirow{2}{*}{ Mistakes } & \multicolumn{5}{|c|}{ Kinds of Mistakes } & \multirow{2}{*}{ Revisions } \\
\hline & & Grammar & Spelling & Diction & Letter & Other & \\
\hline 1. & $\begin{array}{l}\text { The poverty in } \\
\text { Indonesia is very } \\
\text { hgh. }\end{array}$ & & $\sqrt{ }$ & & & & $\begin{array}{l}\text { The poverty in Indonesia is } \\
\text { very high. }\end{array}$ \\
\hline 2. & $\begin{array}{ll}\text { Proverty can be } \\
\text { definend }\end{array}$ & & $\sqrt{ }$ & & & & Proverty can be definend \\
\hline
\end{tabular}

c. Diction

\begin{tabular}{|c|c|c|c|c|c|c|c|}
\hline \multirow{2}{*}{ No } & \multirow{2}{*}{ Mistakes } & \multicolumn{5}{|c|}{ Kinds of mistakes } & \multirow{2}{*}{ Revisions } \\
\hline & & Grammar & Spelling & Diction & Letter & Other & \\
\hline 1. & $\begin{array}{l}\text { We can live healthy } \\
\text { from now. }\end{array}$ & & $\sqrt{ }$ & $\sqrt{ }$ & & & $\begin{array}{l}\text { We can life health from } \\
\text { now. }\end{array}$ \\
\hline 2. & $\begin{array}{l}\text {... where accidents } \\
\text { are fregent. }\end{array}$ & & & $\sqrt{ }$ & & & $\begin{array}{l}\text {... where accidents are } \\
\text { happens. }\end{array}$ \\
\hline
\end{tabular}

d. Letter

\begin{tabular}{|c|c|c|c|c|c|c|c|}
\hline \multirow{2}{*}{ No } & \multirow{2}{*}{ Mistakes } & \multicolumn{5}{|c|}{ Kinds of Mistakes } & \multirow{2}{*}{ Revisions } \\
\hline & & Grammar & Spelling & Diction & Letter & Other & \\
\hline 1. & $\begin{array}{l}\text { Most oF the people } \\
\text { From the low level. }\end{array}$ & & & & $\sqrt{ }$ & & $\begin{array}{l}\text { Most of the people from } \\
\text { the low level. }\end{array}$ \\
\hline 2. & $\begin{array}{l}\text { Like open a job } \underline{\text { And }} \\
\text { give some money to } \\
\text { survive. }\end{array}$ & & & & $\sqrt{ }$ & & $\begin{array}{l}\text { Like open a job and give } \\
\text { some money to survive. }\end{array}$ \\
\hline
\end{tabular}


The analysis results are shown that the students still must understand the aspects of writing. Most of the participants still could not revise the mistakes well. In grammar problems, there were seen very clear, but the revision was not done well.

\section{Data 1: $\underline{\text { Proverty }} \underline{\text { can be definend }} \rightarrow$ Proverty can be} definen

2: Governments of developing countries often cannot afford to provide .... $\rightarrow$ Governments of developing countries are often cannot afford to provide....

3: For the rich people should contribute.... $\rightarrow$ For the rich people should contributed ....

4: Love can cause a positive effect. Love can caused a positive effect.

5: You ordered to get in... $\rightarrow$ You should to get in....

6: ... still much another causing... $\rightarrow$. another factors causing...

7: Almost all of the traffic accident preceded by infraction rules of traffic.

Almost all of the traffic accident was preceded by infraction rules of traffic.

8: You still let yourself to drive $\rightarrow$ You are still let yourself to drive

Most problems come from grammar. It can be concluded that from the data above the participant who is as the second person still could not do the revision well. In data 1 , the first writer wanted to have passive sentence, but the second person who revised it did not apply the correct rule. Next in data 2, 3, 4 and 5, the first writer used modal auxiliary "can and should". Furthermore the second person concluded that the form of the sentence is wrong, but actually it has been right. The second person has overlapped the modal and be auxiliary, and also modal must always be followed by 1 not verb 2 or preposition to. While in data 6 , the first and the second person had not applied the correct rule for having singular or plural form in the sentence. In data 7 , the student is not aware that the subject is plural, so the auxiliary verb must be "were" not "was". In data 8, the student as the first writer has been right in writing the sentence, but then the second person claimed that the sentence must be completed with "are".

The second aspect is spelling. The revision is not only grammar, but also spelling and vocabulary. In this case, the participants had analyzed some sentences in which considered as they have wrong spelling. In data 1 , the conclusion has been alright. While in data 2 , the second person still did not revise the wrong spelling done by the first writer.

Data 1: The poverty in Indonesia is very hgh. $\rightarrow$ The poverty in Indonesia is very high.

2: Proverty can be definend $\longrightarrow$ Proverty can be definend

The third aspect is diction. The diction which is considered as wrong is in the choice of word verb "live" and adj "healthy" becomes noun "life" and noun "health". In other word, the second person did not know that the first sentence has been right. Next in data 2, the second person revised the diction of the first writer. $\mathrm{He}$ considered that his friend used slang word "fregent" and it must be "happens". In this case, grammar problem was also appeared. There was an overlap verb are and happen.

Data 1: We can live healthy from now. $\rightarrow$ We can life health from now.

2: ... where accidents are fregent... $\longrightarrow \ldots$ where accidents are happens.

The third aspect is letter. In data 1 and 2 below, the participants had revised well. Otherwise, the first writer applied upper-case letter in the middle of a sentence, and the second person had done revision well.

Data 1: Most oF the people From the low level $\rightarrow$ Most of the people from the low level.

2: Like open a job And give some money to survive. $\rightarrow$ Like open a job and give some money to survive.

\section{Conclusion}

This study explored the competence of the participants to apply peer feedback on EFL writing by Indonesian university students. However, the result revealed that the participants still need to understand the aspects of writing a lot more. Otherwise, they did not revise well. The participants still analyzed in wrong way. This study has also aim to build students awareness. It must be presented to avoid the same mistake done by their friends or even themselves. Moreover, most of the students found the mistakes in grammar instead of other mistakes.

The analysis in the surface change is actually the limitation of this study. However, further examination is urgent to do in the future. The study can be explored by specifying the methodology on the revision change. 


\section{References}

Cai, J. (2011). A contrastive study of on line peer feedback and online teacher feedback in teaching English writing to college students. Foreign Language World, 134 (2), 65 -72.

Cheng, W. and Warren, M. (1996). Hong Kong students' attitudes toward peer assessment in English language courses. Asian Journal of English Language Teaching, 6, 61-75.

Hedin, B. (2012). Peer Feedback in Academic Writing Using Google Docs. LTHs 7:e Pedagogiska Inspirationskonferens

Hyland, K. and Hyland, F. (2006) Feedback in second language writing: Contexts and issues. Cambridge University Press.

Lei, C. 2012. Relations among Peer Feedback, Writing Performance and Writing Improvement: Evidence from a Writing Class in China. Reflecting Education Journal, Vol 8, No. 1, July 2012, pp.10-23.

Topping, K.E. Smith, I., Swanson, and Elliot, A. (2000). Formative peer assessment of academic writing between postgraduate students. Assessment and Evaluation In Higher Education, 25 (2), 149-169.

Wakabayashi, R. (2008). The effect of peer feedback on EFL writing: Focusing on Japanese university students. OnCUE Journal, 2(2), 92-110. 